\title{
A Research on Practical Teaching Model Innovation of the Marketing Major in Applied Undergraduate Universities
}

\author{
Lisha Ma \\ Yunnan University Of Bussiness Management, Kunming City, Yunnan \\ Province, 650106, China
}

\begin{abstract}
Under the new situation, enterprise marketing has to face internationalization and digitization. Therefore, society requires that marketing professionals must be equipped with an international vision, digital technology, innovative consciousness and practical ability. Based on the author's learning and teaching experience, this paper firstly analyzed the demand of marketing talents in enterprises, and then discussed the existing problems in practical teaching of the marketing major in applied undergraduate universities. Finally, this article proposed fresh attempts for the practical teaching innovation of the marketing major.

Keywords: Applied undergraduate universities; Marketing; Practical teaching; Teaching model; Innovation
\end{abstract}

\section{Introduction}

At present, the marketing major in undergraduate universities in China often focuses on theoretical research, while the research on practical teaching is generally deficient. Even though some schools have studied practical teaching, the research is not systematic, coherent and scientific. For example, Guangzhou University just introduces case teaching just from the perspective of practical teaching methods; Beijing Technology and Business University carries out reform of marketing courses and the practical teaching is just wedged content scattered in several courses[1]. In other words, these universities do not recognize 
the importance of practical teaching. On the other side, students just get perceptual cognizance of the marketing major. When it comes to the actual work, it will take a long time for them to adapt to the job or role transition. Therefore, it is necessary to reform and innovate the practical teaching of the marketing major.

\section{Enterprise's Demand for Marketing Talents under the Current Situation}

\subsection{Marketing talents with an international vision and international business activity ability}

The integration of the world economy requires enterprises to conform to the international business development model, so that marketing personnel must have the international concept, consciousness and knowledge structure. In addition to high political and ideological quality and healthy psychological quality, marketing talents should have a broad international vision and strong sense of innovation and team cooperation. Besides, they are supposed to master marketing theories well and possess intercultural communicative competence. Moreover, marketing people ought to know international practice and business rules well and have the ability to use and handle information, so that they can independently engage in international business activities[2].

\subsection{Marketing talents with the Internet and digital applied technology and capabilities}

The demand analysis of talents released by China Southern Talent Market in April 2015 shows that the demand of marketing professionals still occupied the top slot in the first quarter. With the penetration of the Internet into traditional industries, traditional businesses start to conduct E-commerce and the demand of Internet + talents increases continuously. Therefore, the competition for Ecommerce talents with a solid Internet and digital applied technology and capabilities between enterprises intensifies.

\subsection{Marketing talents with innovation and practical ability that meets the needs of the times}

With the advent of internationalization and digitization, the marketing environment faced by enterprises is complex and constantly changing. Enterprises' marketing activities are confronted with more challenges and innovation is a powerful guarantee for enterprises to be in an invincible position and to achieve sustainable development. This requires that the marketing staff must have an excellent innovative quality, keen observation ability, advancing innovative thinking, abundant innovative knowledge and practical ability[3]. Therefore, the reserve and cultivation of innovative marketing talents has become the main demand direction of many enterprises. In addition, in order to cope with 
the fierce market competition, enterprises also put forward new demands to the marketing professionals. Enterprises hope that the newly recruited marketing professionals can become familiar with their own work as soon as possible and quickly play their role in the company.

\section{Problems in Practical Teaching of the Marketing Major in Applied Undergraduate Universities}

Practical teaching is an important part of professional education and an inevitable trend and objective requirement of the development of higher education. The practical teaching of the marketing major can be divided into two aspects: offcampus internship and on-campus practical teaching. Off-campus internship usually contains the internship in companies and short-term market training. Oncampus practical teaching refers to the professional courses and various practical courses in training programs, such as skill competitions, vocational qualification examinations, science and technology lectures and literary contests.

\subsection{The stability of off-campus practice base is difficult to be guaranteed}

Marketing off-campus practice bases are generally marketing departments in various small and medium-sized enterprises. The enterprises' demand of interns shows in two ways: one is to cultivate students as reserve talents. After the expiration of the internship, students can formally join the enterprise to work. The other is to take students as front-line sales staff. The former requires a limited number of personnel and students need to take a series of written examinations and interview assessments. The process of this type of practice is formal and students can gain more knowledge and experience. The latter type can meet the demand of the whole class internship and it is convenient for schools to manage internship students. However, this kind of practice is single and it is difficult for students to complete the internship[4]. Off-campus internships in undergraduate universities are generally short-term and the internship period is often a month or two months (usually in summer vacation). Students return to the school to learn after the internship ends. For enterprises, the internship period is short, so that it cannot bring more revenue for them and meet their needs to enrich the sales force. It is difficult to maintain a long time cooperation with schools. Therefore, each class of internship students has different practice bases, which increases communication costs.

\subsection{The internship company lacks standardized training and education for interns}

As local applied undergraduate colleges and universities, their internship companies are mostly local enterprises, most of which are small and mediumsized companies. The training mechanism of such enterprises is usually not perfect and their training and education awareness is weak. These companies lack 
pre-service training and education, and they just choose students who can work directly in the front-line sales promotion. Students cannot quickly adapt to the role and the work pressure directly from the school learning environment to the first-line market. This has a great negative impact on their self-confidence and enthusiasm, which will affect the internship effect ultimately.

\subsection{The practice guidance and follow-up of schools is not enough}

During the internship, the school assigns professional teachers as instructors for the trainee student, who will direct students to complete the internship task successfully. Before the formulation of the internship program, most of the school supervisors do not enter the enterprise to investigate the working environment and work content of the enterprise marketing. They lack practical teaching and guidance experience, and their off-campus practice guidance are just inspection work without any professional guidance content[5].

\subsection{The internship and teaching content comes apart}

In on-campus practice teaching, hours of professional courses account for more than one-third of the total hours. The curriculum syllabus neglects the content of practice teaching and standardized teaching methods. In actual teaching, practical teaching is only the simulation learning of computer software. School practical courses have the corresponding credits and the term is fixed. Besides, the teaching and assessment are more standardized, but these courses are usually elective courses for the whole schools. Actually, the real and major-related practice content is insufficient.

\subsection{Practical teaching assessment methods and class arrangement cannot meet the needs of marketing major}

At present, the assessment method of undergraduate colleges and universities is usually limited to written examinations. However, students' practical skills, communication competence and market development proficiency required by marketing major courses can not be fully reflected by the examination paper. The score of test paper cannot reflect students' understanding of professional knowledge and it cannot represent their ability to use professional knowledge.

\section{Fresh Attempts for the Practical Teaching of the Marketing Major}

\subsection{The design of course practical teaching model}

The practical teaching of marketing course aims to apply the knowledge and conduct special training of marketing practice on the premise that students grasp the basic knowledge of marketing theories. It pays attention to practicality and implementation, and closely combine the practical problems of marketing positions and enterprise market to improve students' marketing ability. Teaching 
methods include expository method, group discussion method, case study method, simulation method, role-playing method, special lectures and hands-on practice. Teaching methods encourage students to think diligently and speak boldly; it focuses on divergent thinking and encouraging students to develop the habit of writing reports[6]. This method abandons the idea of the completion of operations and takes the actual implementation of enterprise requirements as assessment criteria to simulate the business environment and conduct market behavior. The evaluation of teaching effectiveness includes the writing level of theoretical knowledge tests, lectures, speeches, creativity, profundity, thesis, analysis reports and plans and other documents, the using level of marketing tool and the evaluation of actual marketing performance.

\subsection{The teaching model of simulation laboratory}

Universities should construct an effective risk-free marketing environment by combining virtual reality technology and Internet communication technology, where students can play the role of corporate marketing directors, analyze marketing cases from all angles, and make marketing decisions to get decisionmaking results and make the decision in the next stage. This kind of simulation marketing practice can not only improve students' interest to enhance the teaching effect and ensure the quality of teaching and training, but also can avoid the decision-making risk in the actual process. Marketing simulation experiment is an experiential interactive learning, which integrates role playing, case analysis and expert diagnosis into one. The prominent feature of the simulation experiment is that students can learn knowledge by participating in it. In the actual exercise, students will encounter a variety of typical problems in business, including the overall marketing strategy, product development, pricing, production arrangements, advertising strategy, capital demand planning, marketing and sales, financial and economic indicator analysis and team communication and construction.

\subsection{The improvement of teaching practice bases}

The practical teaching plays an irreplaceable role in the marketing major. At present, the major has established teaching practice bases to develop students' practical ability. First, schools should make full use of resources in provincial demonstration experimental centers. The Business Administration Laboratory of the Economic Management Comprehensive Demonstration Experimental Center funded by the Hubei Provincial Department of Education may assume the tasks to teach marketing, marketing research, business negotiations and other courses. Second, universities may take full advantage of the internship training bases built by Ministry of Finance[7]. Ministry of Finance has set up some distinctive disciplines in colleges with local governments, such as Business and Marketing Training Base and the Modern Logistics Training Base, which has positive influence on improving the experimental conditions of the marketing major experiments and enhancing experimental strength. Third, colleges ought to make the best of school-enterprise internship resources. Currently, it is possible 
to build a stable and deep-seated professional practice base by utilizing the existing resources of the enterprise which cooperates with schools.

\section{Conclusion}

Taking into consideration that local enterprises have a great demand for marketing personnel, the practical teaching in applied undergraduate universities should establish stable off-campus practice bases with multiple forms. According to the enterprise demand at that time, students can combine the centralized and decentralized internship to take professional training. For the school, this article is a new idea of active teaching reform and a new exploration to seek great development of applied disciplines.

\section{References}

[1] Zhao Shide, Pan Zelun. A Research on Practical Teaching System of the Marketing Major in Applied Undergraduate Universities. Journal of Huangshan University, 02, pp.109-112, 2014.

[2] Ou Haiyan. A Discussion on Practical Teaching Reform of the Marketing Major in Applied Undergraduate Universities. China Electric Power Education, 27, pp.73-74 +79, 2014.

[3] Luo Zhiming. A Research on Practical Teaching Course System of the Marketing Major in Applied Undergraduate Universities. Management and Technology of SME ( On Trimonthly Publication), 01, pp.306-307, 2015.

[4] Yan Lixia. A Discussion on Practical Teaching Reform of the Marketing Major in Applied Undergraduate Universities. China Off-campus Education, 14, pp.71-72, 2010 .

[5] Zhang Lin. A Research on the Construction of Practical Teaching System of the Marketing Major in Applied Undergraduate Universities. China Electric Power Education, 08, pp.109-110, 2012.

[6] Chu Xiaoqing. A Research on Practical Teaching of the Marketing Major in Applied Undergraduate Universities. Journal of Baicheng Normal University, 12, pp.24-27, 2015.

[7] Zhang Xiao. A Research on the Construction of Practical Teaching System of the Marketing Major in Applied Undergraduate Universities. Chizi (On Trimonthly Publication), 16, pp.126-127, 2016. 